\title{
On the Fiscal Policy in Malaysia: An Econometrical Analysis Between the Revenue - and Expenditure
}

\author{
Marco Mele $^{1}$, Angelo Quarto ${ }^{2} \&$ Cristiana Abbafati ${ }^{2}$ \\ ${ }^{1}$ University of Teramo, Italy \\ ${ }^{2}$ Sapienza University of Rome, Italy \\ Correspondence: Marco Mele, University of Teramo, Italy. E-mail: mmele@unite.it
}

Received: October 29, 2019

Accepted: December 4, 2019

Online Published: March 5, 2020

doi:10.5430/rwe.v11n1p1

URL: https://doi.org/10.5430/rwe.v11n1p1

\begin{abstract}
This study aims to assess the relationship between government spending and government revenue in Malaysia. The study of the causal relationship between revenue and public expenditure has important implications for the choices of fiscal policies in the field of public finances. So, this study uses annual data for the period between 1985 - 2016 with Zivot and Andrews (1992) methods and Granger causality tests. Our results sustain the spend-and-tax hypothesis highlights how the increase in tax pressure is the wrong method to contain budget deficits. In fact, in addition to reducing the disposable income of households, a tax policy of this type would reduce savings. Therefore, also the investment. All this would hurt Malaysia's economic growth.
\end{abstract}

Keywords: fiscal policy, government spending and revenue, budget deficit, Malaysia, Granger causality tests

JEL codes: E62, C4.

\section{Introduction}

The revenue and expenditure are the components of the fiscal policy. The combination of fiscal policies influence, beyond the monetary ones, economic growth. In developing countries, revenues are mainly represented by direct and indirect fiscal pressure and by international trade. However, the distortions that characterize these countries and the volatility of the exchange rate don't allow optimal allocation of resources. Therefore, countries in the developing world, very often, showed persistent deficits of the state budget with higher expenditure outputs. In the long run, this situation generates adverse conditions to the economic system: rising inflation, rising interest rates, shrinking investments, slowing growth and exchange rate depreciation.

In Malaysia, fiscal policy has been used as the primary tool for economic growth. In particular, the discretion in its use by policymakers was the primary choice in the phases of the recessionary economic cycle: the increase in public spending, reduction of fiscal pressure. The decision to use fiscal policies as a determinant for economic growth was taken during the Asian financial crisis in 1997. However, this choice caused profound public budget imbalances that caused persistent deficits from 1998 to 2018 (Figure 1). 


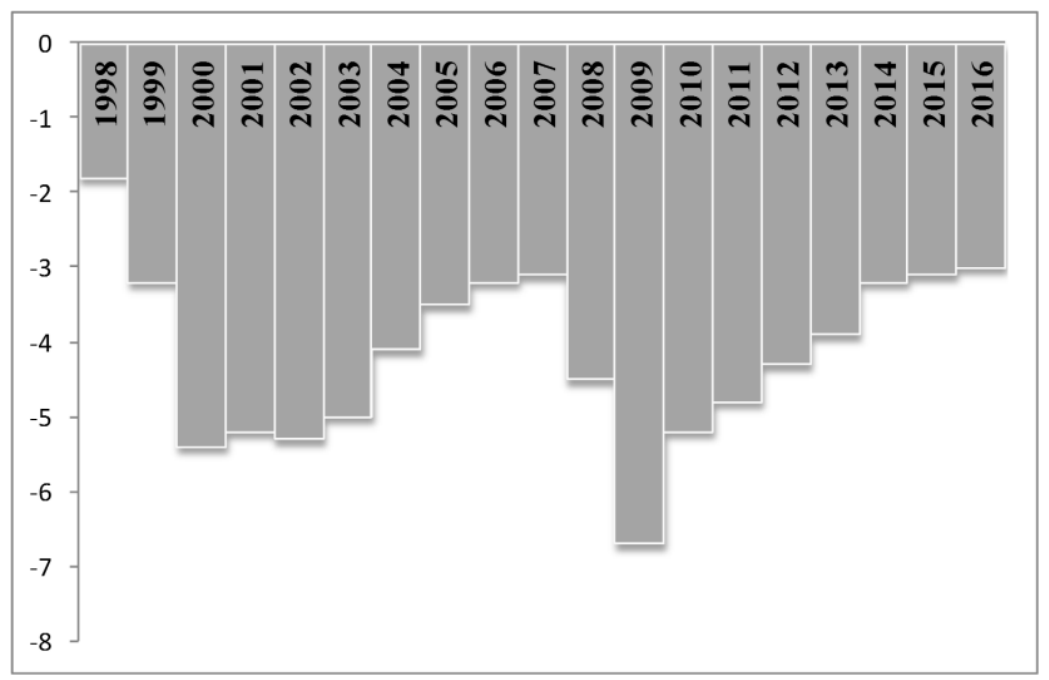

Figure 1. Malaysia Government Budget, 1998-2016.

\section{Percent of GDP}

Source: our processing on data: Bank Negara Malaysia, CBM.

The choice to use Keynesian policies was important. The Asian crisis has risked a critical effort in the country to avoid a long-term recessionary process. Therefore, Malaysia had to abandon the idea of reducing the budget deficit to encourage aggregate demand. However, since 2002, economic policy has begun aimed at limiting public spending, as we can see from Fig.1. The budget deficit has been decreasing over the years. Despite these efforts, the US international crisis broke out in 2007-2008. It has had massive repercussions at the international level, with a collapse in world demand. Malaysia has also suffered this crisis and again, has had to undertake economic policies in deficit balancing. Therefore, only since 2014, the public deficit has started to decline again.

This study, based on the choices of policymakers in Malaysia, wants to verify causal relationships between government revenue and expenditure in a period of severe economic decisions. In other words, we will try to prove the spend-and-tax hypothesis. Using cointegration analysis and error correction models, we will perform inference analyzes. In section II we will make a brief overview of the literature relating to the studies covered by this work; in part III we will discuss the methodology and the data used in the analysis, carrying out an empirical analysis; while section IV will be dedicated to concluding remarks.

\section{Economic Background}

In Malaysia, fiscal policy is an instrument for financing the country's infrastructure. They are necessary for long-term and qualitative economic growth. A discretionary fiscal economic policy, like the one used in Malaysia, is crucial since it represents a pro-cyclical choice during economic crises. Therefore, Malaysia also uses a discretionary fiscal policy to counteract the economic slowdown (Vijayaledchumy, 2003). These fiscal choices are the increase in public spending, capital expenditure, and the reduction of the tax burden. In this situation, the deficits accumulated over the years are not the consequence of inefficient economic choices such as, for example, accommodating redistribution policies. In Malaysia, economic policies to stimulate the economy are used during recessionary periods. In fact, they were used during the 1997 Asian financial crisis and in the most recent international crisis of 2007-2008. Kim et al. 2014, highlights how the ratio between domestic debt / gross product has increased in recent years due to these discretionary choices necessary to face the international crisis. In fact, Malaysia has been experiencing a growing internal deficit since the beginning of the 2007 international sub-prime mortgage crisis. Therefore, we can say that economic turbulence is the cause of the country's persistent internal deficits. As we can see from fig.1, the highest deficit occurred in 2009. In fact, the deficit recorded value as a percentage of GDP of $6.13 \%$. As a consequence, also, the debt / GDP ratio has increased. Kim et al. (2014), however, in his paper, how the financing of the internal deficit was simple. This result, following the indications of Barro and Ricardo, was made possible thanks to the ample domestic liquidity that allows us to offer loans at reasonable interest rates. 
Nevertheless, this inherent advantage may not persist. If the economic clichés turn out to be negative, recourse to private loans will be more difficult. This can be explained concerning a hypothetical contraction of aggregate demand and, therefore, also of household savings. The international economic crises and the use of a discretionary fiscal policy also increased the debt-to-GDP ratio from 32\% in 1997 to $55 \%$ in 2013 . Given that economic theories have not been able to respond effectively to this problem, policymakers have failed to implement containment policies. Tang et al. (2013) state that in a standard Keynesian model, when public spending increases, there will be an increase in higher output than public expenditure used. However, in reality, output growth could be influenced by other factors. They are the regime of exchange and trade international that would coexist the fiscal policy multiplier. In fact, in contrast, fiscal policy would not be relevant. Indeed, in the Ricardian equivalence theory, economic agents would reduce current consumption after an increase in public spending. They are aware that the tax burden will increase to reduce the new deficit caused by the increase in public spending. Besides, the accumulation of an accommodative fiscal policy could, in the IS-LM model, crowd out private investments. This situation would reduce the effectiveness of the expansionary public spending policy. Finally, the authors affirm that the theory of "expansive fiscal contraction", an increase in fiscal expenditure, is accompanied by the phenomenon of uncertainty. With uncertainty, low credibility in government policies could reduce the desire for current consumption. This situation would generate adverse effects that would affect the internal deficit and economic growth. Jitsuchon (2010), on the other hand, points out that the effects of the fiscal stimulus depend on their effect of autocorrelation over time. In fact, economic policy choices are valid if they can contribute to growth in all sectors of the economy. Since the transmission of these effects takes time, the economic system must be able to oil the transmission mechanism between the sectors over the years.

As for the current situation, from 2 November 2018, the Malaysian Minister of Economy presented in Parliament the budget for 2019-2020, the first of the new Government. The financial position of the country, if on the one hand, is weakened by the increase in debt (up to $65.5 \%$ of GDP according to the latest estimates) and the public deficit (expected at $3.7 \%$ of GDP in 2018) and financial liabilities unplanned, on the other hand it is reinforced by higher revenues in the oil \& gas sector (which is worth $15 \%$ of GDP) whose revenues should reach 54 billion ringgits in 2019, double compared to 2018 (one euro equals 4,72 ringgits at current exchange rate). The new version of the budget, therefore, covers the two years 2018-2020 and includes among its objectives sustainable development, inclusive growth, greater competitiveness of the country at the international level, promotion of investments, the strengthening of infrastructures, a regulatory reform for fight embezzlement and corruption, and fiscal consolidation. The maneuver is openly aimed at restoring public finances, put to the test by previous Governments, to ensure a gradual fiscal consolidation bringing the deficit / GDP ratio to 3.4 in 2019 and 3.0 and 2.8\% respectively in 2020 and 2021. Not for this reason, the Government will only use austerity and rigor measures, instead of foreseeing comprehensive policies that should lead to a GDP growth of 4.9\% in 2019 (compared to 4.8 this year). Moreover, the fiscal policy maneuver lays the foundation for a program of regulatory reforms aimed at curbing waste and corruption. On the revenue side, the budget must first deal with the resources needed to compensate for the lower-income deriving from the replacement, starting from 1 September 2018, of the "Goods and Services Tax" (GST, multi-stage value-added tax) with the "Sales and Services Tax" (SST, single-phase tax levied by manufacturers only). The latter takes into account $38 \%$ of the reference goods of the consumer price index against $60 \%$ of the GST and is applicable only to producers with a turnover exceeding 1.5 million ringgit. In 2019 it is expected that the SST will guarantee revenues for a total of 21 billion against the 44 that would have been collected with the GST. To bridge the gap, a series of measures to rationalize public spending is envisaged, from the use of revenues from the oil \& gas sector to the introduction of new taxes (airport exit fee, sugar tax, digital service tax), from the disposal of public assets to review, postponement or suspension of some of the planned infrastructure projects, whose financing will henceforth be entered in the budget (unlike in the past). Overall spending is expected to grow (by 2019) by $8 \%$ compared to 2018 , for a total of 314.5 billion ringgits. If, however, the 37 billion of financial liabilities of the previous management not entered in the balance sheet are subtracted (mostly tax rebates not yet paid and lower revenues deriving from the GST), the expense is reduced to 277.5 billion ringgits, down by 3 , $1 \%$ compared to 2018. A share of 54.7 billion is allocated to investments for the development of the country (development expenditure), of which 29.2 billion of economic incentives for transport, trade, industry, energy, public services, and agriculture. The remaining portion is intended for operating expenditure. Among the ministries, the Education Department (60 billion) will receive the most significant endowment, demonstrating the importance given by the Government to educational and vocational training programs. In this regard, the budget has allocated 2.9 billion to guarantee access to education for the less well-off population and has earmarked a good 3.8 billion in loans and scholarships. 


\section{Literature Survey}

Many authors have always studied the effects of fiscal policies on the economy. Numerous studies have also been carried out concerning the relationship between revenue and expenditure. They can be subdivided about the causal relationship that the survey wants to carry out: tax-and-spend or revenue-and-spend hypothesis; spend-and-tax hypothesis or spend-and-revenue hypothesis; fiscal synchronization hypothesis. The first hypothesis states that by increasing revenues, public spending will also increase, and therefore there will be an imbalance in the general budget. To avoid this situation should be put in place policies to support the demand to increase revenue. The second states that increases in public spending required during recessive economic cycles but will be temporary. They, therefore, will subsequently lead to improvements in revenue too. The third provides for the existence of a bidirectional relationship between tax and spending.

Since the literature on this subject is extensive, we will discuss the principal authors, and then, we will enrich this part through tables of more extensive documentation with a part dedicated only to Malaysia's case.

Friedman (1978), part of the first hypothesis, shows how changes in government revenue generate changes in government spending. Therefore, the economist points out that the tax increases will lead to improvements in spending, limiting the possibility of reducing the budget deficits that are generated over time. Buchanan and Wagner (1978) agree with Friedman, but they confront the problem under a different view. For them, increases in public spending are caused by indirect tax pressure.

Peacock and Wiseman (1979) advocates of the spend-tax hypothesis, claim that temporary increases in government expenditures that have been generated in recessive economic cycles lead to a permanent increase in government revenues. This situation is the "displacement effect."

Musgrave (1988) and Meltzer and Richard (1981), belong to the third hypothesis. They act on the political election cycle, assert that revenue and expenditure shall be determined jointly. In this way, the fiscal synchronization hypothesis comes to life.

Concerning the empirical literature, it can be divided according to different periods analyzed, specific observations on delays and methodology. Usually, the econometric method used is the Granger test within a vector autoregressive model; other studies, instead, examine the Granger causality test through a model of error correction.

To support the tax-spend hypothesis Blackley (1986), Ram (1988a), Bohn (1991), and Hoover and Sheffrin (1992) analyze the US case. Their study yields different results than other authors. Indeed, Anderson et al. (1986), Von Furstenberg et al. (1986), Jones and Joulfaian (1991), and Ross and Payne (1998) find, again for the USA, confirmation in the spend-tax hypothesis.

Ahiakpor and Amirkhalkhali (1989) and Payne (1997) analyze the case of Canada, confirming the tax-spend hypothesis.

Using panel cointegration models, Ram (1988b) analyzes a group of developing countries (El Salvador, Philippines, Thailand, Honduras, New Zealand) and developed countries (United Kingdom) finding for some confirmation of the spend-tax hypothesis, for others of fiscal synchronization. Joulfaian and Mookerjee (1991) carry out a study of OECD countries. They reach different results based on the type of state analyzed: for Italy and Canada, there is support for the tax-spend hypothesis; France, Japan, Germany, Finland, United States, United Kingdom, Greece, and Austria confirm the spend-tax hypothesis; Ireland the fiscal synchronization hypothesis.

Table 1. Some results of existing literature

\begin{tabular}{lll}
\hline Year & Author(s) & Key findings \\
\hline 1978 & Friedman & $\begin{array}{l}\text { Tax-and-Spend hypothesis. Changes in government revenue cause changes in } \\
\text { government expenditure. The author, therefore, states that the increase in taxes leads to } \\
\text { higher expenses. }\end{array}$ \\
\hline 1979 & $\begin{array}{l}\text { Peacock and } \\
\text { Wiseman }\end{array}$ & $\begin{array}{l}\text { Spend-and-Tax hypothesis. They say that public spending increases with the growth of } \\
\text { the economy. This is because when income levels increase, tax revenues also increase } \\
\text { since they have constant tax rates. }\end{array}$ \\
\hline 1978 & $\begin{array}{l}\text { Buchanan and } \\
\text { Wagner }\end{array}$ & $\begin{array}{l}\text { They claim that taxes hurt government spending. This is because citizens tend to believe } \\
\text { that public services are reduced when the tax burden decreases. Therefore they will } \\
\text { prefer greater public spending. Revenue decreases and expenses increase, resulting in }\end{array}$ \\
\hline
\end{tabular}




\begin{tabular}{|c|c|c|}
\hline & & al deficits. Therefore, taxes must increase in order to resolve fiscal deficits. \\
\hline $\begin{array}{l}1966 \\
1981\end{array}$ & $\begin{array}{l}\text { Musgrave } \\
\text { Meltzer and } \\
\text { Richard }\end{array}$ & $\begin{array}{l}\text { Fiscal synchronization hypothesis. There exists a bidirectional causal relationship } \\
\text { between government expenditure and government revenue. In this hypothesis, public } \\
\text { spending generates government revenues, which in turn cause public spending. In other } \\
\text { words, public spending causes government revenues with a feedback effect. This is } \\
\text { because spending and revenue decisions are made simultaneously over time. The result is } \\
\text { that changes in the economic cycle will also coincide. This theory is supported by the } \\
\text { model of fiscal leveling that finds comfort in the Ricardian' equivalence theory. }\end{array}$ \\
\hline 1994 & $\begin{array}{l}\text { Baghestani } \\
\text { and McNown }\end{array}$ & $\begin{array}{l}\text { Fiscal neutrality hypothesis. Decisions relating to revenue and expenses are made } \\
\text { independent of each other. Therefore, there is no causal relationship between public } \\
\text { expenditure and revenue. The citizenship requirement determines the costs and the } \\
\text { revenues will depend on the maximum amount of taxes that citizens can pay. So it is just } \\
\text { a matter of coincidence that it's possible to achieve a fiscal balance. This is possible } \\
\text { because economic growth, in the long run, ensures that institutions become more } \\
\text { separate and independent. This, therefore, makes it possible to decide separately on } \\
\text { expenses and revenues. }\end{array}$ \\
\hline 2002 & $\begin{array}{l}\text { Chang, Liu } \\
\text { and } \\
\text { Thompson }\end{array}$ & $\begin{array}{l}\text { They study South Korea, Taiwan, and Thailand with a time series 1945-1996. They find } \\
\text { support for the spend-tax hypothesis. }\end{array}$ \\
\hline 2004 & $\begin{array}{l}\text { AbuAl-Foul } \\
\text { and } \\
\text { Baghestani }\end{array}$ & $\begin{array}{l}\text { They study Egypt and Jordan case (1976-2000). There is fiscal synchronization } \\
\text { hypothesis for Jordan. }\end{array}$ \\
\hline 2005 & $\begin{array}{l}\text { Carneiro } \\
\text { et al. }\end{array}$ & $\begin{array}{l}\text { They study Guinea-Bissau over the period } 1981 \text { to } 2002 \text {. This paper is consistent with the } \\
\text { "spend - tax" hypothesis }\end{array}$ \\
\hline 2005 & Narayan & $\begin{array}{l}\text { The author carries out a study concerning Indonesia, Singapore, Sri Lanka and Nepal } \\
\text { Egypt, Jordan (1960-2000). Short-run tax-and-spend hypothesis is applicable. }\end{array}$ \\
\hline 2008 & $\begin{array}{l}\text { Eita and } \\
\text { Mbazima }\end{array}$ & $\begin{array}{l}\text { They study Namibia case with time series 1977-2007. They find spend-tax hypothesis. } \\
\text { Fiscal imbalances can be mitigated government revenue. }\end{array}$ \\
\hline 2012 & $\begin{array}{l}\text { Magazzino, } \\
\text { Mele }\end{array}$ & $\begin{array}{l}\text { The authors analyzing the determinant of health expenditure in Italian Region they come, } \\
\text { indirectly, to the conclusion of the tax-spend hypothesis. }\end{array}$ \\
\hline 2015 & $\begin{array}{l}\text { Magazzino, } \\
\text { Giolli, Mele }\end{array}$ & $\begin{array}{l}\text { The authors analyzing the displacement effect in European Union Countries with time } \\
\text { series 1980-2010 find spend-tax hypothesis. }\end{array}$ \\
\hline 2019 & Mele & $\begin{array}{l}\text { This paper investigates the sustainability of Italian national accounts with a hypothetical } \\
\text { Flat Tax. He use a time series approach and Toda-Yamamoto test to check if the high tax } \\
\text { pressure causes low growth in Italy. }\end{array}$ \\
\hline
\end{tabular}

Concerning the case of Malaysia, there are numerous studies.

Table 2. Some results of existing literature for Malaysia

\begin{tabular}{|c|c|c|c|}
\hline Author(s) & Countries & Time period & Results \\
\hline $\begin{array}{l}\text { Sinha } \\
(1998)\end{array}$ & Malaysia & $1950-1992$ & $\begin{array}{c}\text { Taxation policies always reflect on } \\
\text { government spending }\end{array}$ \\
\hline $\begin{array}{l}\text { Mithani et al } \\
\text { (1999) }\end{array}$ & Malaysia & 1970-1994 & $\begin{array}{l}\text { Supporting the spend-and tax hypothesis in } \\
\text { the short run }\end{array}$ \\
\hline $\begin{array}{l}\text { Aziz et al. } \\
\text { (2001) }\end{array}$ & Malaysia & $1960-1996$ & $\begin{array}{l}\text { There is bidirectional causality between tax } \\
\text { and expenditure }\end{array}$ \\
\hline Sen and Kian Ping (2005) & Malaysia & $1965-2002$ & $\begin{array}{l}\text { There is a long-run relationship between } \\
\text { tax and expenditure. This study support the } \\
\text { tax-and-spend hypothesis }\end{array}$ \\
\hline Taha et al. & & & There is the existence of a long-run \\
\hline
\end{tabular}




\begin{tabular}{cccc}
\hline (2008) & Malaysia & $1970-2006$ & $\begin{array}{c}\text { relationship between tax revenues and } \\
\text { government spending with unidirectional } \\
\text { and bidirectional causality. }\end{array}$ \\
$\begin{array}{c}\text { Hong } \\
\text { (2009) }\end{array}$ & Malaysia & $\begin{array}{c}\text { Government revenue and expenditure are } \\
\text { cointegrated and results support the } \\
\text { spend-and-tax hypothesis } \\
(2011)\end{array}$ & $\begin{array}{c}\text { There is a unidirectional causality from tax } \\
\text { to government spending. }\end{array}$ \\
Ullah & Malaysia & $1970-2009$ & $\begin{array}{c}\text { There is theoretical relationship between } \\
\text { the revenue and the expenditure. }\end{array}$ \\
\hline
\end{tabular}

\section{Data and Empirical Findings}

The empirical analysis aims to analyze the presence of a causal relationship between government spending and revenue for Malaysia. For our study, we use 1985-2016 annual data, taken of annual issues related to Bank Negara Malaysia (BNM). Table 3 shows the variables used in our empirical analyses where $\mathrm{Rv}$ is government revenue, Sp is government spending. The STATA v.14 software was used for data processing.

Table 3. List of the variables (Note 1)

\begin{tabular}{ccc}
\hline Variable & Explanation & Source \\
\hline $\mathrm{Rv}$ & Government revenue, \% of GDP & BNM \\
$\mathrm{Sp}$ & government spending, \% of GDP & BNM \\
\hline
\end{tabular}

For this work, to avoid distortions in the analysis, the variables used were calculated in the logarithmic terms. In Table 3 , an exploratory data analysis is given.

Table 4. Exploratory data analysis

\begin{tabular}{lrrrrrrrr}
\hline Variable & \multicolumn{1}{c}{ Mean } & Median & Minimum & Maximum & Skewness & Kurtosis & 10-Trim & \multicolumn{1}{l}{ IQR } \\
\hline Rv & 10,377 & 10,491 & 9,4727 & 10,922 & $-0,6766$ & 2,101 & 10,47 & 0,7114 \\
\hline Sp. & 9,922 & 10,043 & 8,9872 & 10,758 & $-0,09$ & 1,405 & 9,11 & 1,4759 \\
\hline
\end{tabular}

As we can see mean present a positive value for $\mathrm{Rv}$ and $\mathrm{Sp}$; 10-Trim values are near the mean; the inter-quartile range shows the absence of outliers.

The correlation analysis in Table 5 shows how the variables are strongly correlated.

Table 5. Correlation analysis

\begin{tabular}{lll}
\hline & $\mathrm{Rv}$ & $\mathrm{Sp}$ \\
\hline $\mathrm{Rv}$ & - & 0.92108843 \\
\hline $\mathrm{Sp}$ & 0.92108843 & - \\
\hline
\end{tabular}

Since our dataset represents a historical series, it is necessary to verify the presence of trends and non-stationarity about our variables and so, we use the Augmented Dickey-Fuller (ADF) in Table 6. 
Table 6. Augmented Dickey-Fuller-criterion AIC

Level

First-Difference

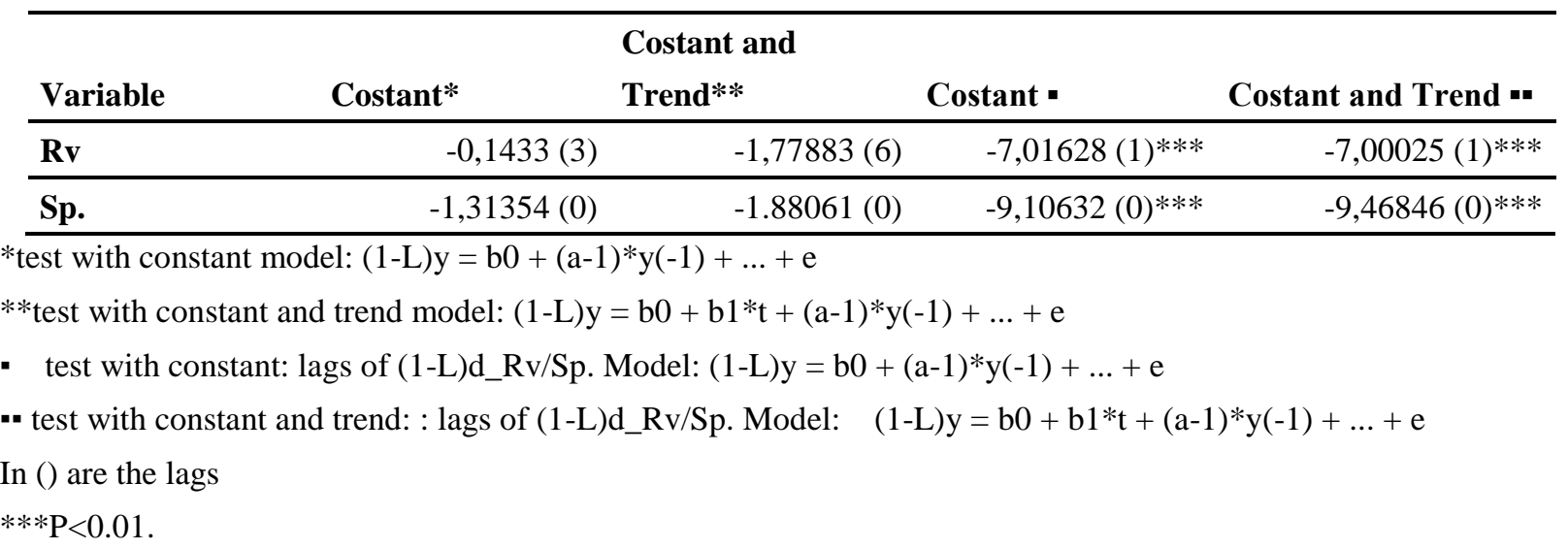

The results in Table 6 show: in relation to ocular inspection process all the value in time series dataset don't satisfy the stationary criterion. On the contrary, this is so when we use the first difference. We can say that the our dataset the variables are integrated into $\mathrm{I}(1)$.

To verify also the presence of abnormal values consistent with the economic cycle theory, we will use Perron (1989) and Zivot and Andrews (1992) methods -results in Table 7. We will limit, certain years that have caused various anomalous international turbulences: 1998 (Asian crisis); 2007 (US financial crisis). In particular, we will apply the Perron' specification:

$$
Y_{t}=\mu+\delta D U_{t}+\beta_{t}+\partial D T_{t}+d D\left(T_{\theta}\right)_{t}+\sigma y_{t-1}+\sum_{i=1}^{k} c_{i} \Delta y_{t-1}+\varepsilon_{t}
$$

We assume that: $1<T_{t}<T$ and it is our breaking point in the series; $D\left(T_{\theta}\right)=1$ when $t=T_{\theta}+1$, otherwise its value will be $0 . \mathrm{DU}_{\mathrm{t}}=1$ if $\mathrm{t}>\mathrm{T}_{\mathrm{k}}$, otherwise its value will be $0 . \mathrm{Y}_{\mathrm{t}}$ represents our variables (Rv and $\left.\mathrm{Sp}\right) ; \mu, \delta, \partial, \beta, \mathrm{d}, \alpha, \mathrm{c}_{\mathrm{i}}$ these are the parameters that theoretically must be estimated; $\Delta$ is the first difference and $\varepsilon$ is a generic stochastic error. After, according to Zivot and Andrews we choose, through Student t ratio the structural break where the null hypothesis of a random walk drift will not be accepted.

Table 7. Results about single structural break

\begin{tabular}{llrrrrr}
\hline Variable & $\mathbf{O B P}$ & $\mathbf{k}$ & \multicolumn{1}{c}{ t-stat } & \multicolumn{2}{c}{$\mathbf{5 \%}$ critical value } \\
\hline $\mathbf{R v}$ & 1998 & 1 & $-1,007$ & $-3,560$ \\
\hline $\mathbf{S p}$ & 2007 & 1 & $-1,721$ & $-3,560$ \\
\hline $\mathbf{\Delta \mathbf { R v }}$ & 1998 & 0 & $-3,752 * * *$ & $-3,560$ \\
\cline { 2 - 6 } & $\mathbf{\Delta} \mathbf{S p}$ & 2007 & 2 & $-2,997 * * *$ & $-3,560$ \\
\hline
\end{tabular}

The results obtained show how, despite the structural break and the tests at the first differences, we are unable to reject the null of a unit root. The results confirm the economic theory. The years 1998 with $\mathrm{K}=1$ and $\mathrm{K}=0$ represent the effects of integration of the Asian financial crisis. It has had significant budget deficits necessary for social policies to combat the financial and economic crisis. Instead, relative to the year 2007 present in $\mathrm{K}=0$ and $\mathrm{K}$ $=2$ it represents the effects of the international financial crisis of subprime mortgages. The adverse effects of this crisis on the balance sheet of Malaysia are attributable to the absence of liquidity in the banking sector. In fact, this international crisis generated a distrust effect in the interbank sector, which represents $80 \%$ of the liquidity in circulation. The difficulty of inter-bank money circulation generated the reduction of loans from banks to companies. 
Therefore, at the macroeconomic level, business investments were reduced. The consequence was a recovery of GDP with rising unemployment. To avoid continuous negative effects over time, the state intervened through expansive fiscal policies necessary to sustain aggregate demand. Such interviews, however, generated public budget deficits not covered by revenue. The choice economically proved to be suitable.

We can confirm, therefore, that are I(1) processes. After this situation, we use to estimate the causal link between government revenue and government spending in Malaysia, Granger causality tests in Table 8. So we the following regression as it was shown in Granger (1969):

$$
\begin{aligned}
& \mathrm{X}_{1 \mathrm{t}}=\delta_{1}+\sum_{\mathrm{i}=1}^{\mathrm{p}} \mathrm{a}_{\mathrm{i}} \mathrm{X}_{1 \mathrm{t}-\mathrm{i}}+\sum_{\mathrm{i}=1}^{\mathrm{p}} \mathrm{b}_{\mathrm{i}} \mathrm{X}_{2 \mathrm{t}-\mathrm{i}}+\mathrm{u}_{1 \mathrm{t}} \\
& \mathrm{X}_{2 \mathrm{t}}=\delta_{2}+\sum_{\mathrm{i}=1}^{\mathrm{p}} \mathrm{c}_{\mathrm{i}} \mathrm{X}_{1 \mathrm{t}-\mathrm{i}}+\sum_{\mathrm{i}=1}^{\mathrm{p}} \mathrm{d}_{\mathrm{i}} \mathrm{X}_{2 \mathrm{t}-\mathrm{i}}+\mathrm{u}_{2 \mathrm{t}}
\end{aligned}
$$

Where $\mathrm{X}_{1 \mathrm{t}}$ is $\mathrm{Rv} ; \mathrm{X}_{2 \mathrm{t}}$ is $\mathrm{Sp} ; \delta_{1}$ and $\delta_{2}$ are constant terms, $u_{1 t}$ and $u_{2 t}$ are white noise series and $p$ represents the lag order.

Table 8. Results for Granger causality tests

\begin{tabular}{cccc}
\hline Country & Granger & $\chi^{2}$ & P-Value \\
& causality & & \\
\hline Malaysia & $\mathrm{Sp} \rightarrow \mathrm{Rv}$ & 12.45 & $0.0006^{* * *}$ \\
& $\mathrm{Rv} \rightarrow \mathrm{Sp}$ & 4,17 & 0.1256 \\
\hline
\end{tabular}

$* * * p<0.01, * * p<0.05$, and $* p<0.10$

In Table 8, we show the causality test results. This result confirms the spend-and-tax hypothesis: increases in government spending would, therefore, raise taxes. This situation puts us at the root of the conviction that to reduce the budget deficit, and it is necessary to act on ways to contain expenditure. Thus, it is not possible to move only by increasing the tax burden. Most likely, Malaysia has to carry out reforms related to the containment of public welfare spending policies promoting, instead, choices that help increase employment. A policy of privatization could generate a possible reduction in spending. It would increase state revenues without causing a reduction in household disposable income. Compared to the literature of references, our paper highlighted some essential elements. The need for precise analysis of the mechanisms that determine the trend of public spending and the identification of interventions aimed at containment and its progressive redevelopment became, from our estimation, fundamental themes of financial and budgetary policy. In particular, we recommend transversal reductions in spending appropriations. This is possible through linear cuts in budgetary provisions relating, in particular, to discretionary expenditure for intermediate consumption, as well as reductions in transfers and spending authorizations directly regulated by law.

\section{Conclusion}

The process of globalization, the numerous financial crises from that of 1997 to that of 2008 have drawn economic decline in the last three decades in the area of South-East Asia. Although the countries belonging to this region have registered new growth rates, the economic crises have caused many changes in Malaysia relative to the public budget. They are a challenge for the Malaysian government as it has to face the link between macroeconomic stability and sustainable public budget. In this situation, the economic literature believes that budgets in excessive deficits cause poor economic presumptions in developing countries. About Malaysia, however, the discontinuity between income and expenditure is due to the deficits recorded during the 1997 crisis. Therefore, we can say that it represents an exogenous variable and not a persistent element in the economy of Malaysia. Therefore, a study that considers the relationship between tax revenues and public spending is essential to evaluate the government's choices for the country's economic growth and the top allocation of resources.

This investigation aims to determine the causal relationship between the expenditure and revenue of government in the case of Malaysia by using the Granger causality tests. From the analysis in time series with a dataset $1985-2016$, we confirm for Malaysia the spend-and-revenue hypothesis. This hypothesis suggests that the government should find different funds to finance public spending. Indeed, continuing to follow the spend-and-revenue hypothesis, the government will continue to generate budget deficits over the long term. Therefore, according to Ricardian equivalence theory, Malaysia will seek funds through domestic or international loans. However, in the absence of an 
expansive economic cycle, the Malaysian government will increase taxes to repay debt interest rates. The government to avoid this situation, should optimize public spending and aim for a policy of privatization.

\section{References}

AbuAl-Foul, B., \& Baghestani, H. (2004). The causal relation between government revenue and spending: Evidence from Egypt and Jordan. Journal of Economics and Finance, 28, 260-269.

Ahiakpor, J. C. W., \& Amirkhalkhali, S. (1989). On the Difficulty of Eliminating Deficits with Higher Taxes. Southern Economic Journal, 56, 24-31.

Anderson, W., Wallace, M. S., \& Warner, J. T. (1986, January). Government Spending and Taxation: What Causes What?. Southern Economic Journal, 630-639.

Aziz, M. A., Habibullah, M. S., Azman-Saini, W. N. W., \& Azali, M. (2000). Testing for Causality between Taxation and Government Spending: An Application of Toda-Yamamoto Approach. Pertanika Journal of Social Sciences \& Humanities, 8(1), 45-50.

Blackley, P. R. (1986). Causality between Revenues and Expenditures and the Size of the Federal Budget. Public Finance Quarterly, 14(2), 139-156.

Buchanan, J., \& Wagner, R. (1978). Dialogues concerning fiscal religion. Journal of Monetary Economics, 4, 627-636.

Chang, T., Liu, W. R., \& Thompson, H. (2002). The viability of fiscal policy in South Korea, Taiwan, and Thailand. ASEAN Economic Bulletin, 19, 170-177.

Eita, J. H., \& Mbazima, D. (2008). The Causal Relationship Between Government Expenditure and Revenue in Namibia. Journal of Economic and Financial Sciences, 2(2), 175-186.

Friedman, M. (1978). The limitations of tax limitation. Policy Review, 7-14.

Granger, C. W. J. (1969). Investigating causal relations by econometric models and cross-spectral methods. Econometrica, 37(3), 424-438.

Hong, J. (2009). Tax-and-Spend or Spend-and-Tax? Empirical Evidence from Malaysia. Asian academy of Management Journal of Accounting and Finance, 5(1), 107-115.

Hoover, K. D., \& Sheffrin, S. M. (1992). Causation, Spending, and Taxes: Sand in the Sandbox or the Tax Collector for the Welfare State?. American Economic Review, 82(1), 225-248.

Jitsuchon, S. (2010). Fiscal policy issues in Thailand after the current economic crisis. Paper presented at conference on global financial and economic crisis, Tokyo. Retrieved from https://ideas.repec.org/a/mof/journl/ppr010h.html

Jones, J. D., \& Joulfaian, D. (1991). Federal Government Expenditures and Revenues in the Early Years of the American Republic: Evidence from 1792-1860. Journal of Macro- economics, 13(1), 133-155.

Joulfaian, D., \& Mookerjee, R. (1990a). The Government Revenue-Expenditure Nexus: Evidence from a State. Public Finance Quarterly, 18(1), 92-103.

Kian-Ping, L, Melvin, J., \& Liew, V. K-S. (2005). Statistical inadequacy of GARCH models for Asian stock markets: evidence and implications. Journal of Emerging Market Finance, 4(3), 263-279.

Kim, A., Brendan, D., Ha, C. H., Eckerd, G. E., Foo, S., Qureshi, Z., \& Zaidi, I. (2014). Economic policy in Malaysia: Paths to growth. The Woodrow Wilson School's Graduate Policy Workshop.

Loganathan, N., Kogid, M., \& Suriyani, M. N. S. (2011). Tax Revenue and Government Spending Constraints: Empirical Evidence from Malaysia. China-USA Business Review, 10(9), 779-784.

Magazzino, C., \& Mele, M. (2012). The Determinant of Health Expenditure in Italian Regions. International Journal of Economics and Finance, 4(3), 61-72.

Magazzino, C., Giolli, L., \& Mele, M. (2015). Wagner's Law and Peacock and Wiseman's Displacement Effect in European Union Countries: A Panel Data Study. International Journal of Economics and Financial Issues, 5(3), 812-819.

Mele, M. (2019). On Italy's Flat Tax Needs and Sustainability of the Public Budget. Research in World Economy, $10(3)$. 
Meltzer, A., \& Richard, S. F. (1981). A rational theory of the size of government. Journal of Political Economy, 89, 914-927.

Mithani, D. M., \& Goh Soo Khoon. (1999). Causality between government expenditure and revenue in Malaysia: A seasonal cointegration test. ASEAN Economic Bulletin, 16, 68-79.

Musgrave, R. (1988). Public finance in Theory and Practice. New York: McGraw-Hill Book Company.

Narayan, P. K. (2005). The government revenue and government expenditure nexus: Empirical evidence from the nine Asian countries. Journal of Asian Economics, 15, 1203-1216.

Payne, J. E. (1997). The tax-spend debate: the case of Canada. Applied Economics Letters, 4, 381-386.

Peacock, A., \& Wiseman, J. (1979). Approaches to the Analysis of Government Expenditure Growth. Public Finance Quarterly, 7, 3-23.

Perron, P. (1989). The great crash, the oil price shock and the unit root hypothesis. Econometrica, 57(6), 1361-1401.

Ram, R. (1988a, January). Additional Evidence on Causality between Government Revenue and Government Expenditure. Southern Economic Journal, 763-769.

Ram, R. (1988b). A Multicountry Perspective on Causality between Government Revenue and Government Expenditure. Public Finance, 43, 261-269.

Ross, K. L., \& Payne, J. E. (1998, January). A Re-Examination of Budgetary Disequilibria. Public Finance Review, 26(1), 67-79.

Sinha, D. (1998). Government Expenditure and Economic Growth in Malaysia. Journal of Economic Development, 23(2), 71-80

Taha, R., \& Loganathan, N. (2008). Causality between Tax Revenue and Government Spending in Malaysia. The International Journal of Business and Finance Research, 2(2), 63-73.

Tang, H. C., Liu, P., \& Cheung, E. C. (2013). Changing impact of fiscal policy on selected ASEAN countries. Journal of Asian Economics, 24, 103-116.

Ullah, N. (2016). The Relationship of Government Revenue and Government Expenditure: A case study of Malaysia. MPRA. Retrieved from https://mpra.ub.uni-muenchen.de/id/eprint/69123

Vijayaledchumy, V. (2003). Fiscal policy in Malaysia. In Fiscal Issues and Central Banking in Emerging Economies BIS Papers No 20, edited by Monetary and Economic Department, 173-179. Basel, Switzerland: Bank for International Settlements.

Von Furstenberg, G. M, Green, R. J., \& Jeong, J. (1986, May). Tax and Spend, or Spend and Tax? Review of Economics and Statistics, 179-188.

Zivot, E., \& Andrews, D. W. K. (1992). Further evidence on the Great Crash, the oil price shock and the unit root hypothesis. Journal of Business and Economic Statistics, 10(3), 251-270.

\section{Note}

Note 1. See the website: http://www.bnm.gov.my/index.php?ch=statistic\&lang=en. 